\title{
Quality Issues in the Expansion of University Education in Kenya, the Human Resource Challenges and Opportunities
}

\author{
Charles Kombo Okioga, Erick Nyakundi Onsongo, Yobes Benjamin Nyaboga \\ Kisii University College, Kisii, Kenya
}

\begin{abstract}
This paper gives an analysis of the quality issues in the expansion of university education in Kenya examining the human resource challenges and opportunities. It examines a variety of factors that impact the nature, content, and mode of delivery of the teaching. The paper is an introduction and highlights the importance of higher education to societal development. It observes that higher education enables individuals to develop their capabilities to the highest potential, serves the needs of an adaptive, sustainable and knowledge based economy and plays a major role in shaping a democratic, civilized and inclusive society. It is thus seen as the key to progress in the 21st century. It examines government policy with respect to education in general and higher education in particular. It is noted that the government recognizes the important role that education plays to foster national development and has therefore through various policy instruments sought to ensure that access, relevance, and quality become the major areas of the development of higher education in the country. The management of the universities in the country has faced serious human resource challenges. These challenges arise from the fact that the rapid expansion of university education in the country has not been accompanied with provision of resources in order to maintain high standards, quality, and relevance. This in turn has negatively affected the quality and relevance of the programmes. It is recommended that in order to enhance the quality of teaching, research, and service delivery.
\end{abstract}

Keywords: higher education, research, expansion

\section{Introduction to the Study}

Higher education has developed in numerous ways since the end of World War II. Throughout the world, issues such as autonomy and accountability, the impact of technology, the growing role of markets and the privatization of higher education, the role of research and teaching, various efforts toward curriculum reform, and the massive expansion that has characterized higher education systems in most countries have all played important roles in the development of higher education. Universities are international institutions, with common historical roots, and at the same time are embedded in national cultures and circumstances (Chacha, 2004).

Post-secondary education has expanded since World War II in virtually every country around the world. The growth of post-secondary education has, in proportional terms, been more dramatic than that of primary

\footnotetext{
Charles Kombo Okioga, Dr., Department of Business \& Management, Kisii University College. Erick Nyakundi Onsongo, Mr. Department of Business \& management, Kisii University College.

Yobes Benjamin Nyaboga, Dr., Department of Business \& Management, Kisii University College.

Correspondence concerning this article should be addressed to Erick Nyakundi Onsongo, P.O Box 408-40200 Kisii, Kenya. E-mail:erickonsongo@yahoo.com.
} 
and secondary education. Writing in Martin Trow (1975) spoke of the transition from elite to mass and then to universal higher education in the industrialized nations. While the United States enrolled some 30 percent of the relevant age cohort (18-21 year olds) in higher education in the immediate postwar period, European nations generally maintained an elite higher education system, with fewer than 5 percent of the population attending post-secondary institutions. By the 1960s many European nations educated 15 percent or more of this age group in Sweden for example, enrolled 24 percent in 1970, with France at 17 percent. At the same time, the United States increased its proportion to around 50 percent, approaching universal access. By the mid-1990s many European countries, including France, Germany, and the United Kingdom, enrolled around 50 percent of the relevant age group, and the proportion in the United States increased to three-quarters. While Europe and North America are now relatively stable, middle-income countries and countries in the developing world have continued to expand at a rapid rate.

In the Third World, expansion has been similarly dramatic. Building on tiny and extraordinarily elitist universities, higher education expanded rapidly in the immediate post-independence period. In India, enrollments grew from approximately 100,000 at the time of independence in 1947 to over 6.5 million in the 1990s, although India enrolls just 7 percent of the relevant age group. China enrolls a similar number, though this represents only 5 percent of its young people. China, especially, is engaged in a dramatic expansion program. Expansion in Africa has also been rapid, with the post-secondary student population growing from 21,000 in 1960 to 437,000 in 1983, but with growth stagnating in the 1990s as a result of the economic and political difficulties experienced by many sub-Saharan African countries. Recent economic difficulties in much of sub-Saharan Africa have meant that per student expenditure has dropped, contributing to a marked deterioration in academic standards. Enrollment growth has also slowed (Onkeo, 2007).

There are many reasons for the expansion of higher education. A central cause has been the increasing complexity of modern societies and economies, which have demanded a more highly trained workforce. Almost without exception, post-secondary institutions have been called on to provide the required training. Indeed, training in many fields that had once been imparted on the job has become formalized in institutions of higher education. Whole new fields, such as computer science, have come into existence, and many of these rely on universities as a key source of research and training. Nations now developing scientific and industrial capacity, such as Korea and Taiwan, have depended on academic institutions to provide higher level training and research expertise to a greater extent than was the case during the first industrial revolution in Europe.

Not only do academic institutions provide training, they also test and provide certification for many roles and occupations in contemporary society. These roles have been central to universities from their origins in the medieval period, but have been vastly expanded in recent years. A university degree is a prerequisite for an increasing number of occupations in most societies. Indeed, it is fair to say that academic certification is necessary for most positions of power, authority, and prestige in modern societies (Chacha, 2004). This places immense power in the hands of universities. Tests to gain admission to higher education are rites of passage in many societies and are important determinants of future success. Competition within academe varies from country to country, but in most cases an emphasis is also placed on high academic performance and tests in the universities. There are often further examinations to permit entry into specific professions.

The role of the university as an examining body has grown for a number of reasons. As expansion has taken place, it has been necessary to provide ever more competitive sorting mechanisms to control access to high prestige occupations. The universities are also seen as meritocratic institutions that can be trusted to 
provide fair and impartial tests to measure accomplishment honestly and, therefore, determine access. When such mechanisms break down as they did in China during the Cultural Revolution or where they are perceived to be subject to corrupt influences as in India the universities are significantly weakened. And often more ascriptive means of controlling access to prestigious occupations are no longer able to provide the controls not needed, nor are they perceived as fair. Entirely new fields have developed where no sorting mechanisms existed, and academic institutions have frequently been called upon to provide not only training but also examination and certification (Okwakol, 2008).

Republic of Kenya (2006) expansion has also occurred because the growing segments of the population of modern societies demand it. The middle classes, seeing that academic qualifications are necessary for success, demand access to higher education. Governments generally respond by increasing enrollment. When governments do not move quickly enough, private initiatives frequently establish academic institutions in order to meet the demand. In countries like India, the Philippines, and Bangladesh, a majority of the students are educated in private colleges and universities. At present, there are powerful worldwide trends toward: imposing user fees in the form of higher tuition charges, increasingly stressing private higher education, and defining education as a "private good" in economic terms. These changes are intended to reduce the cost of post-secondary education for governments, while maintaining access, although the long term implications for the quality of, access to, and control over higher education remain unclear.

The demands placed on institutions of higher education to accommodate larger numbers of students and to serve expanding functions have resulted in reforms in higher education in many countries. Much debate has taken place concerning higher education reform in the 1960s and a significant amount of change did take place. It is possible to identify several important factors that contributed both to the debate and to the changes that took place. Without question, the unprecedented student unrest of the period contributed to a sense of disarray in higher education. The unrest was in part precipitated by deteriorating academic conditions that were the result of the rapid expansion. In a few instances, students demanded far reaching reforms, although they did not always propose specific changes. It is worthwhile to examine the contemporary challenges to higher education in comparative perspective, as most issues affect academic performance everywhere (Waiture, 1999).

\section{Higher Education in Kenya: A Historical Perspective}

From a historical perspective, the development of education in Kenya can be put into three distinct periods: the pre-colonial, the colonial, and the post-colonial periods.

\section{Pre-colonial Period}

The pre-colonial education was holistic in nature. It was provided within the context of social and economic organization. It was all embracing and relevant along age group and gender lines. It was designed to ensure that society was able to manage its environment and other natural resources in a beneficial and sustainable manner, live in harmony, practice natural social responsibility and sustain a high degree of moral and ethical values. Moral and ethical values were known and accepted as a way of life by all (Manyasi, 2010).

\section{Colonial period}

Kenya was declared a British protectorate in 1895 and made to be a colony thereafter. The colonial government imposed its own education policies and practices in the process destroying the African traditional education system. This education system was exclusive, discriminatory and organized along racial lines. The 
restrictive and discriminatory nature of this education system was reflected in the racially segregated schools for Europeans, Asians, and Africans. Upward mobility was restricted for the Africans through the rigorous examination system. This restricted the Africans' access to higher education. Some efforts were made by Christian churches to provide for African education, but these were by far inadequate especially with regard to higher education and the education of the girl children. During the colonial era, education for Africans was deliberately restricted. Due to this, at the dawn of political independence, there was lack of skilled indigenous personnel who was required to manage and stimulate economic growth (Eshiwani, 2009).

\section{Post-colonial Era}

On the attainment of political independence in 1963, the Kenyan Government produced a blue print to guide the development process entitled "African Socialism and Its Application to Planning in Kenya". In this policy document, education and training of skilled manpower are recognized as one of the pillars of the development process. In this regard the report noted "Growth also requires ample supplies of skilled, trained and experienced Manpower... The provision of education and training to all Kenyans is fundamental to the success of the government's overall development strategy" (Republic of Kenya, 2006). In this document the long term objectives of higher education are indicated as to enhance the ability of Kenyans to preserve and utilize the environment for productive gain and sustainable livelihoods. The development of quality human resource as a key element in the attainment of national goals for industrial development. Education is necessary for the development and protection of democratic institutions and human rights. The dawn of political independence brought with it great enthusiasm amongst Kenyans for education. The government on its part came up with programs to assist Kenyans to access to education, the aim being to remove injustices of the past and to deal with the challenges of independence. Since then Kenya has witnessed a rapid growth in demand for education in general and higher education in particular.

Mwiria (1994) indicated that in a steady growing population the government should have a policy aimed at increasing access to higher education. The Government policy of free primary education has tremendously expanded enrolment of the basic education level. The restructuring of the economy and subsequent growth in demand for certain university based skills, globalization has increased the demand for international qualifications and skills offered through a university education.

On the attainment of political independence in 1963, the government recognized the importance of education for national development. It sought to ensure that access, relevance and quality became the major areas of focus, the aim being to remove the injustices of the former colonial government and to deal with the challenges of independence. There are a variety of policy instruments which have guided the development and influenced decision-making in the education sector. These can be put into two main parts: the pieces of legislation on education development plans, reports of commissions, working party and committees. The main pieces of legislation on the education sector include: The constitution of Kenya, The Board of Adult Education Act, The Higher Education Loans Board Act, The Industrial Training Act, The Education Act and the various Acts establishing in public universities. The Education Act confers upon the minister the responsibility for the promotion of education, the progressive development of institutions devoted to the promotion of education and the coordination of all public bodies concerned with policy on education. The ministry is empowered to make regulations governing the preparations and approval of curriculum, syllabuses, books and other educational materials. At independence, the education system was structured on the British Model of 7-4-2-3(seven years of 
primary education, four years of secondary education, two years of high school, and three years of a basic bachelor's degree). From 1992 following the Mackay' report, there was a shift to the 8-4-4 model of the American system with eight years of primary education, four years of secondary education followed by four years of a basic bachelor's degree (Republic of Kenya, 2006).

The entry to university after secondary education resulted in a dramatic increase in university enrolment. This enrolment was further enhanced by the opening up of the public universities to privately sponsored students under the "Parallel degree programs". Since this expansion was not accompanied by a commensurate increase in human resource, the result has been a steady decline in quality and increasingly serious questions about its relevance (Mwiria \& Nyukuri, 1994).

From 1970, after the dissolution of the university of East Africa, the development of university education has over time been guided by acts of Parliament and funded by the government treasury. There are two types of university education in the country: public and private. The concept of a public university refers to an institution of higher learning established and fully funded by the state. Currently there are seven such universities. Some of these institutions have constituent and campus colleges located in various parts of the country. The Acts of Parliament that established these universities clearly spell out their vision, mission, powers, governance and financing.

All universities state in their constitutive instruments that one of the key functions and objects of a university institution is to provide facilities for research. However, the acts do not specify what percentage of the annual university budget should be set aside for research, and nothing is said of the contribution of industry to applied researches at the universities. Furthermore, no research fund is created to give direct grant to universities. This has led to a situation where research funding in universities is often given a cavalier treatment. In January 2003, a new government took over in Kenya. It came to power on the promise of a more open, accountable, meritocratic and efficient administration (Mwiria \& Nyukuri, 1994). In the education sector, it introduced a less politicized context which had immediate relevance to the management of Kenya's universities.

The education sector has since embarked on implementation of far reaching reforms. These reforms aim to attain the following aims (Mwiria, 1994): increasing the Gross Enrolment Ratio (GER) of university students from the current $3 \%$ to $10 \%$ by 2015 ; attaining equity in university education enrolment was to reflect the national diversity by 2015; improving quantity and relevance of learning and research for socio-economic transformation of Kenya; creating a culture of innovation through acquisition, creation and application of knowledge; Integrating ICT into university education and increase ICT innovations and research output of Kenyan universities; developing strong university linkages and partnership that enhance mutual learning, research and innovation; and enhancing good governance for effective universities and their contribution to Kenya's socio-economic development.

\section{Expansion of Higher Education in Kenya}

Higher education in Kenya can be said to have started with the establishment of the Royal Technical College of East Africa in 1956 (Olel, 2006). Initially it was meant to provide instruction in courses leading to the Higher National Certificate offered in Britain and to prepare matriculated students through full-time study for university degrees in engineering and commercial courses not affected by Makerere (Mwiria \& Nyukuri, 1994). This college was elevated to the University College of Nairobi in 1963 following the establishment of the University of East Africa with Makerere, Dar-es-Salaam and Nairobi as constituent colleges. In 1970, the 
University of East Africa was dissolved and the University of Nairobi with its constituent college, Kenyatta established by an Act of Parliament. The University of Nairobi has since then grown to be the largest University in eastern and central Africa with over 30,000 students, the highest concentration of scholars and academic programmes (Olel, 2006).

At the time of the attainment of political independence in 1963, Kenya had only one university level institution. This university had an enrolment of about 1,000 students by 1970 (Manyasi, 2010). Since then, however there has been tremendous expansion in higher education not only in terms of numbers of institutions but also in the scope of degree programs and student enrolment. In terms of the number of institutions of higher learning, due to the demand for university education, other public universities have had to be established in addition to the University of Nairobi. These are: Moi University (1984), Kenyatta University (1985), Egerton University (1987), Jomo Kenyatta University of Science and Technology (1994), Maseno University (2000) and Masinde Muliro University of Science and Technology (2007). These public universities have a total of 16 universities affiliated to them.

Apart from the government, private universities in Kenya have emerged as viable options for acquiring higher education. Such universities offer market-driven courses and provide a conducive environment for academic excellence. Most of them have modern infrastructure, including libraries, information and communication technologies that are vital for academic excellence and research. So far, there are 14 registered private universities in the country. Out of these, five are fully chartered and offer their own degrees, six have registration certificates and three operate under a letter of interim authority. The chartered institutions are the University of Eastern Africa, Baraton; Catholic University of Eastern Africa, Daystar; Scott Theological College in Machakos and United States International University (USIU). Those registered but awaiting a charter from the Commission for Higher Education are East Africa School of Theology, Kenya Highlands Bible College; Nairobi Evangelical Graduate School of Theology; Pan Africa Christian College; and St Paul's United Theological College. They offer degrees of universities that are affiliated to abroad. The third category are institutions that have been given a letter of authority to run degree programmes as they await registration and a charter. They are Africa Nazarene University in Ongata Rongai, Kenya Methodist University in Meru, and Kabarak in Nakuru. There are other institutions which have not been registered by the Commission but offer degree programmes from other universities. Some of these are Strathmore, Australian University Institute, the Kenya College of Accountancy, the School of Professional Studies, Kenya Science Teachers College, and Kianda College (Olel, 2006).

Private universities are known for their good performance compared with public universities. This is attributed partly to good facilities and infrastructure and close policing by the Commission for Higher Education (CHE - the national higher education accrediting body), which insists that the institutions adhere to strict standards and regulations. But most importantly, the institutions give valuable education to their students, who pay a lot of money in fees. The universities therefore strive to provide education commensurate with the fees they collect from students. A common trend among private universities and colleges is that they concentrate on business and accountancy courses, which are popular with students because of their marketability.

\section{Human Resource Challenges Facing Public Universities}

Numerous problems facing public universities in Kenya have resulted in a constant rise in unit costs of 
education, declining academic achievement, and the near collapse of physical facilities. There is visible general decay of the good facilities that existed during the 1970s and the early 1980s when the universities enjoyed significant budgets from the government. Around 1990, the Breton Wood institutions put pressure on the government to cut subsidies to the public universities by introducing fees and to stop paying students allowances. This was a hard decision for the government to make given that 75 percent of the country's population on average earns less than Kshs 10,000 (USD 128.2) a month. More than 50 percent of the people live in hard core poverty. Already the government provides only about Kshs 800 million (USD 10.2 million) to assist needy students to study at the universities when it is estimated that at least Kshs 1.5 billion (USD $19,230,769$ ) would be needed to assist all the students in need. Of the students who get government assistance through loans, only 20 to 25 percent ever pay back their loans. This is unfortunate, since repayment replenishes the loan fund, and as such, can be thought of as an investment in future generations of students who will be contributing to national development (Nganga, 2010).

The lecturing process in the university is challenged, lecturing methods are often outmoded. Role learning is common, with instructors doing little more in the classroom than copying their notes onto a blackboard. The student, who is frequently unable to afford a textbook, must then transcribe the notes into a notebook, and those students who regurgitate a credible portion of their notes from memory achieve exam success. These passive approaches to teaching have little value in a world where creativity and flexibility are at a premium. A more enlightened view of learning is urgently needed, emphasizing active intellectual engagement, participation, and discovery, rather than the passive absorption of facts.

Human capital pay is generally very low in relation to that offered by alternative professional occupations. Pay increases are governed by bureaucratic personnel systems that reward long service rather than success in teaching or research. Market forces, which attempt to reward good performance, are seldom used to determine pay in the higher education sector.

While pay disparities make it difficult to attract talented individuals, recruitment procedures are often designed in ways that hinder intellectual growth. Some developing countries have been slow to develop traditions of academic freedom and independent scholarship. Bureaucracy and corruption are common, affecting the selection and treatment of both students and lectures. Favoritism and patronage contribute to academic in breeding that denies universities the benefit of intellectual cross-fertilization. These problems arise most commonly in politicized academic settings, where power rather than merit weighs most heavily when making important decisions.

Politicization can have a wider impact on the atmosphere of a system. While political activity on campuses throughout the world has helped address injustices and promote democracy, in many instances it has also inappropriately disrupted campus life. Research, teaching, and learning are extremely difficult when a few university members, students, and student groups take up positions as combative agents of rival political factions.

Higher education institutions rely on the commitment of the employees. Their consistent presence and availability to students and colleagues have an enormous influence in creating an atmosphere that encourages learning. Yet few institutions in developing countries enforce, or even have, structures against moonlighting and excessive absenteeism. Many staff works part time at several institutions, devote little attention to research or to improving their teaching, and play little or no role in the life of the institutions employing them. Staff members are often more interested in teaching another course often at an unaccredited school rather than 
increasing their presence and commitment to the main institution to with which they are affiliated. With wages so low, it is hard to condemn such behavior (Standa, 2007).

In many institutions, students face difficult conditions for study. Severely overcrowded classes, inadequate library and laboratory facilities, distracting living conditions, and few, if any, student services are the norm. The financial strains currently faced by most universities are making conditions even worse.

Many students start their studies academically unprepared for higher education. Poor basic and secondary education, combined with a lack of selection in the academic system, lie at the root of this problem. Yet rarely does an institution respond by creating remedial programs for inadequately prepared students.

Cultural traditions and infrastructure limitations also lead to students studying subjects which offer limited job opportunities and lead to "educated unemployment". At the same time, there is often a unmet demand for qualified graduates, while in many societies women study subjects that conform to their traditional roles, rather than courses that will maximize their opportunities in the labor market. Better information on the labor market is needed, combined with policies that promote economic growth and labor absorption. Also, many educated people tend to be from wealthier backgrounds and are able to resist taking jobs in locations they consider to be undesirable. Promoting an entrepreneurial culture will encourage the creation of more productive jobs (Ngolovoi, 2006).

Students also face the widespread requirement to choose their area of specialization early in their course, in some cases ahead of matriculation. Once a choice is made, change is frequently difficult or impossible. Such inflexibility closes off options, with students unable to sample courses in different academic areas. Early specialization can prevent costly indecisiveness, but systems that are unforgiving of early "mistakes" do not develop and unleash the true potential of many students.

In addition, capital and operating budgets are poorly coordinated. Major new facilities are built, but then are left with no funds for operation and maintenance. The developing world is littered with deteriorating buildings, inadequate libraries, computer laboratories that are rarely open and scientific equipment that cannot be used for want of supplies and parts. It is often impossible to carry over unspent funds for use in later years, and difficult to win a budget that is higher than the previous year's actual expenditure. This creates a "use-it-or-lose-it environment", resulting in overspending and misspent resources.

The disappearance of a research agenda from these universities has serious consequences. The inability to pursue research isolates the nation's élite scholars and scientists, leaving them unable to keep up with developments in their own fields. As research universities lose their ability to act as a reference point for the rest of the education system, countries quickly find it harder to make key decisions about the international issues affecting them.

In addition to being severely underfunded, sometimes despite their best efforts, many higher education institutions in developing countries lack the authority to make key academic, financial, and personnel decisions. They can also be slow to devolve responsibility for decision-making to constituent departments. Poor governance, in other words, dilutes their ability to spend what money they have.

Gender inequality, and low research capacity are other problems facing the universities in Kenya. The universities are accused of producing graduates who are ill equipped for the world of work. Employers often have to re-train the graduates in a time-consuming and expensive exercise. The universities have not effectively adopted the use of IT. The question of unemployment among graduates and the rush to enroll in universities abroad for courses offered locally at a cheaper cost is disturbing the public universities. Increasingly more 
students are moving to the private universities, while the more affluent ones enroll in universities overseas.

The effects of HIV/AIDS have badly hit the university environment with many professional staff being affected causing further skill problems. On the other hand the World Bank and other donor agencies withheld aid to Kenya for most of the 1990s due to what was referred to as bad governance, endemic official corruption and none implementation of key reforms in the country's economy. The rapidly growing population, declining economic growth, slow degree of industrialization and rural/urban economic activity, debt servicing, and disparity in the distribution of income are additional problems that are being felt in all sectors of the economy and in effect impacting negatively on universities .

The government continues to encourage development of private higher education to complement public institutions as a means of managing the costs of expanding higher education enrolment, increasing the diversity of training programmes, and broadening social participation in higher education. A bill is set to be tabled in parliament that will make it possible for foreign-based universities to establish campuses in Kenya. As a way to encourage private sector involvement in providing education, the government does not set tuition price controls in private universities, but provides mechanisms for accreditation through the Commission for Higher CHE, which supervises the establishment and operations of private universities. Until recently, the government did not extend loans facilities to students studying in private universities. In the past this facility was only available to students admitted to public universities. However, effective from the year of 2000/2001, the government announced measures that would extend loans facilities, not only to students in private universities, but also to postgraduate students in all universities.

While horizontal differentiation is driven by an increased demand for higher education, vertical differentiation is a reaction to demand for a greater diversity of graduates. In general, economic development is associated with a more refined division of labor, and higher education institutions have an essential role to play in imparting necessary skills. The increasing importance of knowledge makes this range of skills in wider demand than ever. Today's developing economy needs not only civil servants, but also a whole host of other professionals such as industrial engineers, pharmacists, and computer scientists. Higher education institutions are adapting and new ones are emerging to provide training and credentials in new areas. As societies accept modern medicine, for example, they establish not only medical schools, but also schools of pharmacy.

Differentiation is spurred on by the relaxation of state regulations, but this poses serious quality problems. The argument that market forces will ensure suitable quality is simplistic. Private institutions often receive public subsidies through tax deductions on financial contributions or donations of physical facilities from public sources, or by accepting students whose tuition is financed by the government. To the extent that competition is driven by cost alone, it is likely to abet the provision of low-quality education. So-called garage universities sometimes disappear as quickly as they appeared, leaving students with severe difficulties in establishing the quality of their credentials.

\section{Conclusions}

In most developing countries higher education exhibits severe deficiencies, with the expansion of the system an aggravating factor. Demand for increased access is likely to continue, with public and private sectors seeking to meet it with an array of new higher education institutions. Rapid and chaotic expansion is usually the result, with the public sector generally underfunded and the private (for-profit) sector having problems establishing quality programs that address anything other than short-term, market-driven needs. A lack of 
information about institutional quality makes it difficult for students to make choices about their education, making it hard to enlist consumer demand in the battle to raise standards. Developing countries are left with a formidable task expanding their higher education system and improving quality, all within continuing budgetary constraints. The authors realize that the differentiation of higher education institutions is not a new phenomenon, as different types of colleges and universities have existed for centuries. What is new, however, is the strength of the forces driving differentiation, the pace at which it is occurring, and the variety of institutions being created. A lack of data on education costs prevents inferences about whether these increased expenditures imply quality changes.

\section{References}

Chacha, N. C. (2004). Reforming higher education in Kenya: Challenges, lessons and opportunities. Presented at the State University of New York workshop with the Parliamentary Committee on Education, Science and Technology, Naivasha, Kenya.

Cheboi, B. (2006, November). Funding patterns and their effects on quality of higher education in Kenya (6th ed.). Presented at Kenyatta University Conference paper. Nairobi.

Eshiwani, G (2009). University expansion in Eastern Africa: Challenges and options in higher education, $39,17-22$. Inter-University Council for East Africa (IUCEA), Newsletter.

Manyasi, B. (2010). OL \& DE as a means of increasing access to higher learning in Kenya. Journal of the Kim School of Management, 1, 123-130.

Mario, M. (2003). Higher education in Mozambique: A case study. Partnership for higher education in Africa. Oxford: University press.

Mwiria, K., \& Nyukuri, M. S. (1994). The management of double intakes: A case of Kenyatta university. Paris. UNESCO: International Institute for Educational Planning.

Nganga. (2010). Financing higher education and the quality of education in tertiary institutions in Kenya. Journal of the KIM School of Management, 1, 33- 41.

Ngolovoi, M. (2006). Means testing of student loans in Kenya. Presented at the Comparative and International Higher Education Policy: Issues and Analysis. Workshop: University at Albany.

Odebero, S. O. (2010, April). Crisis in financing and management of Kenyan higher education: Implications for planning reform agenda. Paper presented at Educational Management Society of Kenya Conference held at Migori Teachers College, April 12-14, 2010.

Okwakol, M. J. N. (2008). Challenges and prospects for quality assurance in science and technology education in African countries. The Uganda Higher Education Review. Journal of the National Council for Higher Education, 5(2), 17-26.

Olel, M. A. (2006). The effect of privately sponsored students programme on efficiency and equity in public universities in Kenya and Uganda (Unpublished Ph.D. thesis, Maseno University).

Onkeo, M. J. (2007). Implications of current means testing procedures for higher education loans on access to university education by undergraduate students in Kenya’s public universities (Unpublished M.Ed thesis, Kenyatta University).

Republic of Kenya. (2006). Transformation of higher education and training in Kenya to secure Kenya's development in knowledge economy: Report of the universities inspection board (Kinyanjui Report), Nairobi: Government Printers.

Standa, E. (2007). Institutional autonomy and academic freedom. The Uganda Higher Education Review. Journal of Higher Council for Education, 4(1), 17-20.

Waituru, M. (1999). Accelerated student enrolments in Kenyan public universities: Implications for quality instruction (Unpublished Master of Education thesis, Kenyatta University).

World Bank. (2000). Higher education in developing countries: Peril and promise. Washington, D. C.: World. 